\title{
UJI TOKSISITAS SUB AKUT INFUS DAUN JARAK PAGAR (Jatropha curcas Linn.) TERHADAP GAMBARAN HISTOLOGI HATI MENCIT
}

\author{
Surya Amal \\ Fakultas Farmasi Universitas Buana Perjuangan Karawang \\ email : surya.amal@ubpkarawang.ac.id
}

\begin{abstract}
Abstrak
Penggunaan daun jarak pagar, khususnya sebagai obat antihipertensi, masih perlu didukung data toksisitas untuk menjamin keamanan pemanfaatannya. Telah dilakukan penelitian pengaruh infus daun jarak pagar (Jatropha curcas Linn.) terhadap gambaran histologi hati mencit (Mus musculus) yang diamati secara mikroskopik. Penelitian ini menggunakan 60 ekor mencit jantan yang dibagi dalam tiga kelompok konsentrasi : kelompok I, $5 \%$ b/v; kelompok II, $10 \%$ b/v; kelompok III, 20 $\%$ b/v ditambah satu kelompok kontrol. Kelompok I, II dan III serta kelompok kontrol masingmasing dibagi atas tiga subkelompok berdasarkan lama pemberian (15 hari, 30 hari, 45 hari). Masing-masing subkelompok terdiri dari 5 ekor mencit. Hasil pemeriksaan mikroskopik menunjukkan bahwa pemberian infus daun jarak pagar $5 \% \mathrm{~b} / \mathrm{v}, 10 \% \mathrm{~b} / \mathrm{v}$ dan $20 \% \mathrm{~b} / \mathrm{v}$ peroral sekali sehari dengan dosis $1 \mathrm{ml} / 30$ gram berat badan memengaruhi struktur jaringan hati mencit. Pemberian infus daun jarak pagar $5 \% \mathrm{~b} / \mathrm{v}$ selama 15 hari menunjukkan struktur jaringan hati mencit yang masih dalam batas-batas normal. Kerusakan struktur jaringan hati mencit mulai terlihat setelah pemberian infus daun jarak pagar $5 \%$ b/v selama 30 hari dan 45 hari yang meningkat dengan semakin besarnya konsentrasi dan lamanya masa pemberian. Perhitungan secara statistik dengan menggunakan desain blok lengkap acak menunjukkan bahwa parameter susunan radier sel, sinusoid, membran sel, sitoplasma sel dan inti sel jaringan hati mencit mengalami kerusakan akibat pemberian infus daun jarak pagar $5 \% \mathrm{~b} / \mathrm{v}, 10 \% \mathrm{~b} / \mathrm{v}$ dan $20 \% \mathrm{~b} / \mathrm{v}$ dengan efek yang sangat berbeda nyata.
\end{abstract}

Kata kunci : jarak pagar, histologi hati, infus

Abstract

The use of Jatropha leaves, especially as an antihypertensive drug, still needs to be supported by toxicity data to ensure the safety of its use. Research on the effect of jatropha (Jatropha curcas Linn.) Infusion on mice (Mus musculus) histology was observed microscopically. This study used 60 male mice divided into three concentration groups: group I, 5\% w / v; group II, $10 \%$ w / v; group III, $20 \% \mathrm{w} / \mathrm{v}$ plus one control group. Groups I, II and III and the control group each divided into three subgroups based on the length of administration (15 days, 30 days, 45 days). Each subgroup consists of 5 mice. Microscopic examination results showed that the administration of Jatropha leaf infusion of $5 \% \mathrm{w} / \mathrm{v}, 10 \% \mathrm{w} / \mathrm{v}$ and $20 \% \mathrm{w} / \mathrm{v}$ orally once a day at a dose of $1 \mathrm{ml} /$ 30 grams of body weight affected the structure of the liver tissue of mice. The administration of Jatropha leaf infusion of $5 \% \mathrm{w} / \mathrm{v}$ for 15 days showed that the structure of the liver tissue of mice was still within normal limits. Damage to the structure of the liver tissue of mice began to be seen after administration of Jatropha leaf infusion of 5\% $\mathrm{w} / \mathrm{v}$ for 30 days and 45 days which increased with increasing concentration and length of administration. Statistical calculations using a randomized complete block design showed that the parameters of the cell radier, sinusoid, cell 
membrane, cell cytoplasm and liver cell nuclei of the mice suffered damage due to jatropha leaf infusion of $5 \% \mathrm{w} / \mathrm{v}, 10 \% \mathrm{w} / \mathrm{v}$ and $20 \% \mathrm{~b} / \mathrm{v}$ with a very different effect.

Keywords: jatropha, liver histology, infusion

\section{PENDAHULUAN}

Salah satu tumbuhan yang telah digunakan masyarakat Indonesia sebagai obat tradisional adalah tumbuhan jarak pagar (Jatropha curcas Linn.). Tumbuhan ini berupa perdu yang agak besar, bercabang tidak teratur, berasal dari Amerika, ditanam dan tumbuh liar dimanamana di daerah tropis. Tumbuhan ini banyak digunakan sebagai obat cacing, radang anak telinga, gusi berdarah, eksema, encok, obat gosok, rematik, borok. antimikroba, antioksidan, antikanker, dan antiinflamasi (Baroroh, H.N dan Eka Prasasti Nur Rachmani, E.P.N. 2013).

Pada penelitian sebelumnnya Tedjakusuma, P.I. (1982) melaporkan bahwa penggunaan infus daun jarak pagar (Jatropha curcas Linn.) memberikan efek antihipertensi pada hewan percobaan anjing dengan konsentrasi $10 \%$ b/v, $20 \%$ b/v, dan terutama pada konsentrasi $30 \%$ b/v. Pada penelitian yang lain, Haryono, K dan Soegiarso, N.C (1985) melaporkan efek hipotensif infus daun jarak pagar (Jatropha curcas Linn.) terhadap tikus putih jantan strain Wistar pada konsentrasi 2,5\% b/v, $5 \%$ b/v, $10 \%$ b/v, $20 \%$ b/v dan $40 \%$ b/v (Haryono, K. dan Soegiarso, N.C. (1985).

Tujuan pengobatan hipertensi adalah untuk mencegah terjadinya morbiditas dan mortalitas akibat tekanan darah tinggi. Ini berarti bahwa tekanan darah harus diturunkan dan dipertahankan pada keadaan normal. Bila tidak, mungkin akan mengganggu fungsi organ atau menimbulkan gejala-gejala yang tidak dapat ditolerir. Disamping itu penggunaan antihipertensi pada umumnya dalam waktu yang lama, sehingga perlu diteliti toksisitas subakut pada hewan percobaan. Salah satu uji tokisitas subakut adalah pemeriksaan terhadap jaringan hati.

Penelitian ini dilakukan pada hewan percobaan mencit (Mus musculus) jantan yang diberi infus daun jarak pagar dengan konsentrasi $5 \%$ b/v, $10 \%$ b/v dan $20 \%$ b/v, beserta kelompok kontrol dengan pemberian peroral selama 15 hari, 30 hari dan 45 hari. Apakah 
pemberian infus daun jarak pagar (Jatropha cusrcas Linn.) berpotensi menyebabkan kerusakan jaringan hati mencit?

Hipotesis dari penelitian ini ialah adanya pengaruh pemberian infus daun jarak pagar terhadap kerusakan struktur jaringan hati mencit yang dilakukan dengan pemeriksaan secara mikroskopik.

Penelitian ini dimaksudkan untuk mengetahui pengaruh pemberian infus daun jarak pagar terhadap gambaran histologi hati mencit dengan tujuan untuk memperoleh data ilmiah mengenai toksisitas sub akut infus daun jarak pagar.

\section{METODE PENELITIAN}

Daun jarak pagar (Jatropha curcas Linn.) dikumpulkan dengan memetik daun tua yang masih hijau. Daun jarak pagar (Jatropha curcas Linn.) yang telah dikumpulkan, dibersihkan dengan cara dicuci dengan air, kemudian dikeringkan dengan cara dianginanginkan di tempat yang terlindung dari cahaya matahari langsung. Setelah kering dijadikan serbuk sesuai ayakan 4/18. Selanjutnya dibuat infus dengan konsentrasi $5 \%$ b/v, $10 \% \mathrm{~b} / \mathrm{v}$, dan $20 \% \mathrm{~b} / \mathrm{v}$.

Hewan coba yang digunakan dalam penelitian ini adalah mencit (Mus musculus) jantan dewasa umur tiga sampai lima bulan yang telah dipelihara dan diamati kesehatannya selama dua minggu. Kemudian dipilh yang sehat dan mempunyai berat badan 20-30 gram sebanyak 60 ekor. Mencit dibagi menjadi tiga kelompok perlakuan untuk masing-masing konsentrasi infus daun jarak pagar. Masing-masing kelompok perlakuan dan kontrol dibagi menjadi tiga subkelompok berdasarkan lamanya pemberian (15 hari, 30 hari dan 45 hari). Tiap-tiap subkelompok terdiri dari 5 ekor mencit.

\section{Pembuatan Preparat Mikroskopik}

Mencit dikorbankan dengan cara dislokasi leher, dibedah, diambil organ hatinya, dan dipotong-potong sebesar 5x5x5 mm. Pembuatan preparat mikroskopik dilakukan dengan metode parafin. 


\section{Pengamatan Preparat Mikroskopik dan Pengumpulan Hasil}

Preparat yang telah selesai dibuat, dilakukan pengamatan dengan mikroskop Nikon PFX, kemudian dibuat foto dengan pembesaran $100 \mathrm{X}$ dan $200 \mathrm{X}$. Hasil foto dikumpulkan.

\section{PEMBAHASAN}

Pemberian infus daun jarak pagar dengan konsentrasi $5 \%$ b/v selama 15 hari memperlihatkn gambaran histologi hati mencit yang masih dalam batas normal, terutama pada susunan radier selnya dan batas vena sentralisnya. Pada pemberian selama 30 hari dan 45 hari kerusakan jaringan hati mulai terlihat berupa tanda-tanda stase aliran darah pada hati.
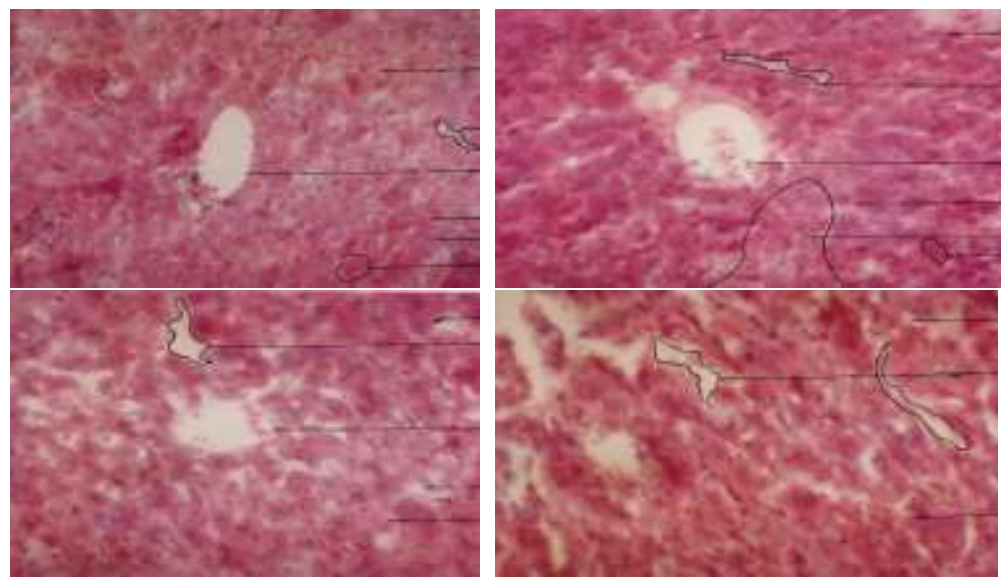

Gambar 1: Foto mikroskopik jaringan hati mencit kelompok perlakuan 30 hari (Keterangan dari kiri ke kanan : kontrol, konsentrasi $5 \%$ b/v, konsentrasi 10 $\% \mathrm{~b} / \mathrm{v}$, dan konsentrasi $20 \% \mathrm{~b} / \mathrm{v}$ )

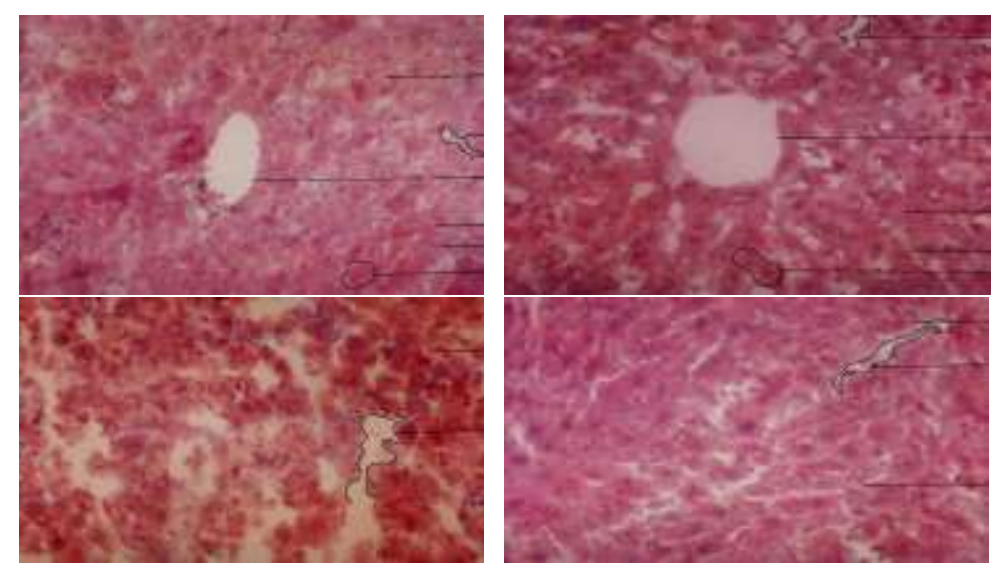

Gambar 2: Foto mikroskopik jaringan hati mencit kelompok perlakuan 45 hari (Keterangan dari kiri ke kanan : kontrol, konsentrasi $5 \%$ b/v, konsentrasi 10 $\% \mathrm{~b} / \mathrm{v}$, dan konsentrasi $20 \% \mathrm{~b} / \mathrm{v}$ 
Pengamatan mikroskopik terhadap beberapa paremeter histologi jaringan hati mencit setelah pemberian infus daun jarak pagar (Jatropha curcas Linn.) untuk masing-masing konsentrasi $5 \%$ b/v, $10 \%$ b/v dan $20 \%$ b/v dapat dilihat pada tabel 1, 2 dan 3 berikut :

Tebel 1. Hasil Pengamatan Mikroskopik Jaringan Hati Mencit Setelah Pemberian Infus Daun Jarak Pagar (Jatropha curcas Linn.) $5 \%$ b/v

\begin{tabular}{|l|l|l|l|l|l|}
\hline No. & $\begin{array}{l}\text { Parameter } \\
\text { Histologi } \\
\text { Hati }\end{array}$ & Kontrol & \multicolumn{3}{|c|}{ Dosis Sehari Selama } \\
\cline { 4 - 6 } & $\begin{array}{l}\text { Susunan } \\
\text { Radier Sel }\end{array}$ & Teratur & Teratur & Teratur & Teratur \\
\hline 2. & Sinusoid & Normal & $\begin{array}{l}\text { Sedikit } \\
\text { melebar }\end{array}$ & Melebar & Melebar \\
\hline 3. & $\begin{array}{l}\text { Vena } \\
\text { Sentralis }\end{array}$ & Jelas & Jelas & $\begin{array}{l}\text { Terdapat } \\
\text { butir } \\
\text { darah } \\
\text { merah }\end{array}$ & $\begin{array}{l}\text { Banyak } \\
\text { butir } \\
\text { darah } \\
\text { merah }\end{array}$ \\
\hline 4. & $\begin{array}{l}\text { Membran } \\
\text { Sel }\end{array}$ & Jelas & Jelas & Jelas & $\begin{array}{l}\text { Beberapa } \\
\text { tak jelas }\end{array}$ \\
\hline 5. & Sitoplasma & Homogen & Homogen & $\begin{array}{l}\text { Beberapa } \\
\text { tidak } \\
\text { homogen }\end{array}$ & $\begin{array}{l}\text { Tidak } \\
\text { homogen }\end{array}$ \\
\hline 6. & Inti sel & Jelas & Jelas & Jelas & Jelas \\
\hline
\end{tabular}

Pemberian infus daun jarak pagar dengan konsentrasi $10 \% \mathrm{~b} / \mathrm{v}$ selama 15 hari mulai memengaruhi gambaran histologi hati mencit. Pada pemberian selama 30 hari dan 45 hari memperlihatkan tingkat kerusakan struktur jaringan sel yang lebih besar, ditandai dengan banyaknya butir darah merah pada vena sentralisnya.

Tabel 2. Hasil Pengamatan Mikroskopik Jaringan Hati Mencit Setelah Pemberian Infus Daun Jarak Pagar (Jatropha curcas Linn.) $10 \%$ b/v.

\begin{tabular}{|l|l|l|l|l|l|}
\hline No. & $\begin{array}{l}\text { Parameter } \\
\text { Histologi } \\
\text { Hati }\end{array}$ & Kontrol & \multicolumn{3}{|c|}{ Dosis Sehari Selama } \\
\cline { 4 - 6 } & $\begin{array}{l}\text { Susunan } \\
\text { Radier Sel }\end{array}$ & Teratur & $\begin{array}{l}\text { Tidak } \\
\text { teratur }\end{array}$ & $\begin{array}{l}\text { Sangat } \\
\text { tidak } \\
\text { teratur }\end{array}$ & Kacau \\
\hline 2. & Sinusoid & Normal & Melebar & Melebar & $\begin{array}{l}\text { Sangat } \\
\text { melebar }\end{array}$ \\
\hline 3. & $\begin{array}{l}\text { Vena } \\
\text { Sentralis }\end{array}$ & Jelas & Jelas & $\begin{array}{l}\text { Terdapat } \\
\text { butir darah } \\
\text { merah }\end{array}$ & $\begin{array}{l}\text { Banyak } \\
\text { butir darah } \\
\text { merah }\end{array}$ \\
\hline
\end{tabular}




\begin{tabular}{|l|l|l|l|l|l|}
\hline 4. & $\begin{array}{l}\text { Membran } \\
\text { Sel }\end{array}$ & Jelas & Tidak Jelas & Tidak jelas & Tidak jelas \\
\hline 5. & Sitoplasma & Homogen & $\begin{array}{l}\text { Tidak } \\
\text { homogen }\end{array}$ & $\begin{array}{l}\text { Ada } \\
\text { vakuola }\end{array}$ & $\begin{array}{l}\text { Banyak } \\
\text { vakuola }\end{array}$ \\
\hline 6. & Inti sel & Jelas & Menghilang & Menghilang & Menghilang \\
\hline
\end{tabular}

Pemberian infus daun jarak pagar dengan konsentrasi $20 \%$ b/v selama 15 hari menyebabkan kerusakan struktur jaringan sel hati mencit. Kerusakan sangat tinggi terlihat pada pemberian selama 30 hari dan 45 hari, dimana hampir semua parameter histologik yang teramati terjadi kerusakan.

Tabel 3. Hasil Pengamatan Mikroskopik Jaringan Hati Mencit Setelah Pemberian Infus Daun Jarak Pagar (Jatropha curcas Linn.) 20 \% b/v.

\begin{tabular}{|l|l|l|l|l|l|}
\hline No. & $\begin{array}{l}\text { Parameter } \\
\text { Histologi } \\
\text { Hati }\end{array}$ & Kontrol & \multicolumn{3}{|c|}{ Dosis Sehari Selama } \\
\cline { 4 - 6 } & $\begin{array}{l}\text { Susunan } \\
\text { Radier Sel }\end{array}$ & Teratur & Kacau & Kacau & Kacau \\
\hline 2. & Sinusoid & Normal & Melebar & $\begin{array}{l}\text { Sangat } \\
\text { melebar }\end{array}$ & $\begin{array}{l}\text { Sangat } \\
\text { melebar }\end{array}$ \\
\hline 3. & $\begin{array}{l}\text { Vena } \\
\text { Sentralis }\end{array}$ & Jelas & $\begin{array}{l}\text { Terdapat } \\
\text { butir darah } \\
\text { merah }\end{array}$ & $\begin{array}{l}\text { Banyak } \\
\text { butir darah } \\
\text { merah }\end{array}$ & $\begin{array}{l}\text { Banyak } \\
\text { butir darah } \\
\text { merah }\end{array}$ \\
\hline 4. & $\begin{array}{l}\text { Membran } \\
\text { Sel }\end{array}$ & Jelas & $\begin{array}{l}\text { Beberapa } \\
\text { tidak jelas }\end{array}$ & Tidak jelas & Tidak jelas \\
\hline 5. & Sitoplasma & Homogen & $\begin{array}{l}\text { Tidak } \\
\text { homogen }\end{array}$ & $\begin{array}{l}\text { Banyak } \\
\text { vakuola }\end{array}$ & $\begin{array}{l}\text { Banyak } \\
\text { vakuola }\end{array}$ \\
\hline 6. & Inti sel & Jelas & Menghilang & Menghilang & Menghilang \\
\hline
\end{tabular}

Berdasarkan pengamatan pada beberapa parameter histologi hati mancit di atas menunjukkan makin besar konsentrasi yang digunakan, serta makin lama waktu pemberian menyebabkan kerusakan struktur jaringan hati mencit yang lebih besar.

Tabel 4. Skor Penilaian Beberapa Parameter Histologi Hati Mencit Setelah Perlakuan Dibandingkan Dengan Kontrol.

\begin{tabular}{|c|c|c|c|c|c|c|c|c|c|c|c|}
\hline \multirow{3}{*}{ No } & \multirow{3}{*}{$\begin{array}{c}\text { Parameter } \\
\text { Histologi } \\
\text { Hati } \\
\text { Mencit }\end{array}$} & \multirow{3}{*}{$\begin{array}{l}\text { Kon } \\
\text {-trol }\end{array}$} & \multicolumn{9}{|c|}{ KONSENTRASI INFUS DAUN JARAK PAGAR } \\
\hline & & & \multicolumn{3}{|c|}{$5 \% \mathrm{~b} / \mathrm{v}$} & \multicolumn{3}{|c|}{$10 \% \mathrm{~b} / \mathrm{v}$} & \multicolumn{3}{|c|}{$20 \% \mathrm{~b} / \mathrm{v}$} \\
\hline & & & $\begin{array}{c}15 \\
\text { hari }\end{array}$ & $\begin{array}{l}30 \\
\text { hari }\end{array}$ & $\begin{array}{l}45 \\
\text { hari }\end{array}$ & $\begin{array}{l}15 \\
\text { hari }\end{array}$ & $\begin{array}{c}30 \\
\text { hari }\end{array}$ & $\begin{array}{l}45 \\
\text { hari }\end{array}$ & $\begin{array}{l}15 \\
\text { hari }\end{array}$ & $\begin{array}{c}30 \\
\text { hari }\end{array}$ & $\begin{array}{l}45 \\
\text { hari }\end{array}$ \\
\hline 1. & $\begin{array}{c}\text { Susunan } \\
\text { Radier Sel }\end{array}$ & 1 & 1 & 1 & 2 & 2 & 3 & 4 & 4 & 5 & 6 \\
\hline 2. & Sinusoid & 1 & 2 & 3 & 4 & 3 & 4 & 5 & 4 & 5 & 6 \\
\hline
\end{tabular}




\begin{tabular}{|c|c|c|c|c|c|c|c|c|c|c|c|}
\hline 3 & $\begin{array}{c}\text { Vena } \\
\text { Sentralis }\end{array}$ & 1 & 1 & 2 & 3 & 1 & 2 & 4 & 3 & 4 & 5 \\
\hline 4. & $\begin{array}{c}\text { Membran } \\
\text { sel }\end{array}$ & 1 & 1 & 1 & 2 & 2 & 3 & 4 & 3 & 4 & 6 \\
\hline 5. & Sitoplasma & 1 & 1 & 2 & 3 & 2 & 3 & 4 & 2 & 5 & 5 \\
\hline 6. & Inti Sel & 1 & 1 & 1 & 1 & 2 & 3 & 4 & 3 & 4 & 5 \\
\hline
\end{tabular}

Keterangan : Makin tinggi nilai skor, kerusakan makin besar

Perhitungan secara statistik dengan menggunakan desain blok lengkap acak menunjukkan bahwa parameter susunan radier sel, sinusoid, membran sel, sitoplasma sel dan inti sel jaringan hati mencit mengalami kerusakan akibat pemberian infus daun jarak pagar $5 \%$ $\mathrm{b} / \mathrm{v}, 10 \% \mathrm{~b} / \mathrm{v}$ dan $20 \% \mathrm{~b} / \mathrm{v}$ dengan efek yang sangat berbeda nyata.

\section{PENUTUP}

Dari hasil penelitian dapat disimpulkan bahwa :

1. Pemberian infus daun jarak pagar dengan konsentrasi $5 \%$ b/v selama 15 hari memperlihatkan gambaran histologi hati mencit yang masih dalam batas normal, dan kerusakan jaringan hati mulai terlihat pada pemberian selama 30 hari dan 45 hari.

2. Pemberian infus daun jarak pagar dengan konsentrasi $10 \% \mathrm{~b} / \mathrm{v}$ dan $20 \% \mathrm{~b} / \mathrm{v}$ memperlihatkan tingkat kerusakan struktur jaringan sel yang teramati makin besar dengan peningkatan konsentrasi dan lama pemberian.

3. Parameter susunan radier sel, sinusoid, membran sel, sitoplasma sel dan inti sel jaringan hati mencit mengalami kerusakan akibat pemberian infus daun jarak pagar $5 \% \mathrm{~b} / \mathrm{v}, 10$ $\% \mathrm{~b} / \mathrm{v}$ dan $20 \% \mathrm{~b} / \mathrm{v}$ dengan efek yang sangat berbeda nyata.

\section{DAFTAR PUSTAKA}

1. Gerber, Michael, A. Thung. Swan, N. (1987). Histology of The Liver. American Journal of Surgical Pathology. 11(9):709-710

2. Baroroh, H.N dan Eka Prasasti Nur Rachmani, E.P.N. 2013. Ketoksikan Akut dari Ekstrak Etanolik Daun Jarak Pagar (Jatropa curcas) pada Mencit Jantan Galur Balb/C. Jurnal Natur Indonesia 15(1), Februari 2013: 52-56

3. Haryono, K. dan Soegiarso, N.C. (1985). Uji Efek Hipotensi Daun Jarak Pagar (Jatropha curcas Linn., Euphorbiaceae) pada Tikus Jantan. Tesis. Sekolah Tinggi Farmasi ITB. Bandung.

4. Tedjakusuma, P.I. (1982). Pengaruh Infus Daun Jarak Pagar (Jatropha curcas, Linn.) Terhadap Tekanan Darah Anjing. Skripsi Sarjana. Jurusan Farmasi F.MIPA Universitas Hasanuddin, Makassar. 
5. Casarett, L.J. and Doull, J. (1986). Toxicology The Basic Science of Poisons. Third edition. Macmillan Publishing. Company. New York. 286-305

6. Jacobsen, N.E. Beck,SD. Jacobson,L.E. Bihrle,R. Einhorn,L.H. Foster,R.S.(2010) Is retroperitoneal histology predictive of liver histology at concurrent postchemotherapy retroperitoneal lymph node dissection and hepatic resection? J Urol.;184(3):Indiana-USA.949-53.

7. Suntoro,S. Handari. (1983). Metode Pewarnaan (Histologi dan Histokimia). Bagian Anatomi dan Mikroteknik Hewan. Fakultas Biologi UGM. Penerbit Bharata Karya Aksara. Jakarta. 22-37. 